\title{
RighteOUSNESS IN THE FACE OF EVIL
}

\section{PAUL R BARTROP}

Genocide scholars study human evil. By contrast, only very rarely have acts of human goodness been examined, with the singular-and crucially important-example of those who tried to save lives during the Holocaust, people recognised by Israel and many around the world as the Righteous among the Nations (Chassidei umot ha-olam). ${ }^{1}$ So little work has been done in respect of goodness during genocide, other than in the Holocaust, that one might despair at the predominance of evil in the world over the relatively few chronicled acts of goodness.

Yad Vashem - the Holocaust Heroes' and Martyr's Remembrance Authority in Israel-is charged with remembering the tragic events of the Holocaust and acknowledging those non-Jews who risked their lives, property or status to save Jews. Soon after the Yad Vashem statute was passed unanimously by Israel's Knesset on 18 May 1953, it was realised that a definition of 'righteous' behaviour was needed. After much redrafting, it was decided

1 On Righteous Gentiles - in an already large literature - see especially Paldiel, Mordecai (2007), The Righteous Among the Nations: Rescuers of Jews during the Holocaust, New York, Harper; Tec, Nechama (1987), When Light Pierced the Darkness: Christian rescue of Jews in Nazi-Occupied Poland, New York, Oxford University Press; Gushee, David P (2003), Righteous Gentiles of the Holocaust: Genocide and moral obligation, 2nd ed, St Paul MN, Paragon House; Tammeus, Bill and Cukierkorn, Rabbi Jacques (2009), They Were Just People: Stories of rescue in Poland during the Holocaust, Columbia MO, University of Missouri Press; Oliner, Samuel P and Oliner, Pearl M (1988), The Altruistic Personality: Rescuers of Jews in Nazi Europe, New York, Free Press. 
that for a person to be classed as 'Righteous', several criteria must first be met, specifically, that only a Jewish party can put forward a nomination; that helping a Jewish family member or individual to convert to Christianity is impermissible; that the assistance given had to have been repeated and/or substantial; and that the assistance had to have been given without any financial gain other than reasonable expenses for rent and food. Since 1963, a commission headed by a justice of the Supreme Court has been charged with investigating and awarding the title of 'Righteous among the Nations' to those fitting the criteria.

On balance, it might be said that the main forms of help extended by the Righteous during the Holocaust fitted one of four main categories: hiding Jews in the rescuer's home or on their property; providing false papers and false identities; smuggling and assisting Jews to escape; and, through various means, rescuing Jewish children. Given the enormous risks involved in rescue efforts, it is remarkable that any of these initiatives took place. This was a time when living space, food, sanitation facilities, and medicine were at a premium, and those who hid Jews risked not only their own lives, but, crucially, those of their families. Depending on where one was located, people caught hiding Jews were, more often than not, executed-either on the spot, or later, in public as an example to others. The eminent Holocaust historian, Christopher Browning, was once asked why there were so few 'Righteous'; his reply was to ask, how come there were so many?2 Despite the immense dangers, by the beginning of January 2012, Yad Vashem had recognised 24,355 men and women from 45 countries as 'Righteous', representing over 10,000 authenticated acts of rescue.

2 Personal communication from Colin Tatz; Browning made this comment at a Macquarie University workshop in the late 1990s. 
It isn't easy being a rescuer. To stand out from the crowd, to refuse to acquiesce, to not compromise one's own values in order to guarantee personal safety at the expense of others these are extremely difficult decisions for people when exposed to extreme situations. Human behaviour during the Holocaust is the paradigmatic example of this, but there have been many other instances, both before and after the Holocaust, that also fit the paradigm. This essay is a first attempt to look at several instances of goodness in genocide beyond the Holocaust. Acts of heroism do not have to be on a grand scale to be effective, and those attempting them do not always have to put their lives on the line when confronting acts of genocidal violence. While showing that there have been some exceptionally brave acts on the part of some individuals, this brief analysis demonstrates that it is in small ways that the worst excesses of genocide can sometimes be avoided.

\section{The nature of 'goodness'}

What do we mean when we speak about goodness in the face of evil? Genocide occurs for several reasons: to eliminate a real or imagined threat, to terrorise a real or potential enemy, to acquire wealth, and in the current context, most frequently to implement a belief or an ideology (for example, racial or ethnic 'purity'). In the latter case, genocide speaks of human dreams: of how we can perfect humanity, or the society in which we live, or the community of which we are part. In attempting to reach such 'perfection', some people deem it both necessary - and even proper - to eliminate those whom they consider impeding their goal. In their view, they do so with the 'best of intentions', and for the current good and guaranteed future of their group. Their victims, on the other hand, have neither a present nor a future, other than as a group that until now has avoided their intended fate.

While this might sound 'reasonable' to some, the twentieth century witnessed dozens of acts of murderous violence. Some were the victims of this violence; others were its 
perpetrators, who planned, carried out, and/or presided over it. Some stood by and watched it unfold, while others took it upon themselves to try to stop it. The perpetrators were committed, for reasons clear to them, to the realisation of the dream of achieving homogeneity, a 'pure' society comprised only of others like themselves, a place representing the closest possible approximation to their 'vision' of human perfection.

Even though perpetrators of genocide saw (and see) themselves as 'noble servants' undertaking a necessary struggle, obviously their victims do not agree. Nor, for the most part, do the vast majority of bystanders, though all too often they are either immobilised by the sheer horror of what they are witnessing, or silently acquiesce in the perpetrators' actions. Practically all agree that the deeds of genocide perpetrators are violent, inhumane, and from the perspective of Western tradition at least, morally wrong. Yet it takes exceptional courage and commitment to stand against them.

Theologians and philosophers are much more concerned about the problem of evil than they are about good. From a religious perspective, some will ask, if God (or the gods) is allloving and all-powerful, why do the wicked prosper and the righteous suffer? While an answer might be that we are too puny to recognise God's Master Plan, but that everything will nonetheless work out for the best in the long run, this is far from acceptable to many secular thinkers, who prefer to look for other reasons to explain the problem of evil. ${ }^{3}$

${ }^{3}$ The problem of evil in the world is a massive one that has occupied the thoughts of philosophers, theologians and dreamers (among others) for millennia. While it is clearly not possible to provide a bibliography of the subject in a single footnote, the following are useful starting points insofar as they also refer to genocide: Wolfe, Alan (2011), Political Evil: What it is and how to combat it, New York, Knopf; Katz, Fred E (1993), Ordinary People and Extraordinary Evil: A 
Very few consider the opposite pole of evil, namely, good. What is a 'good' action? Is it simply the opposite of evil? If evil behaviour is a departure or aberration from the norm, can that norm be labelled as 'good'? And if a person engages in some caring or compassionate action, is that beyond good? Further, does it matter why he or she does it? If a person does something out of the ordinary for the betterment of humanity, by what are their actions motivated? If they feel better by their actions than they did beforehand, are they in fact selfinterested rather than other-interested? In some traditions, the motive matters less than the action, and thus if by virtue of that action a victim might be spared suffering or death, then it doesn't really matter why action was taken. On the other hand, the very notion that a 'good' action is something beyond 'normal' makes one wonder whether that norm is, in fact, ethically neutral until tested. The questions mount up with each successive issue raised. ${ }^{4}$

\section{Goodness during genocide}

Recently one of my seminar students asked: is there a hierarchy of righteousness when we speak about acts of goodness in genocide? An excellent question - the more so as I had been discussing

report on the beguilings of evil, Albany NY, State University of New York Press; Eagleton, Terry (2010), On Evil, New Haven CT, Yale University Press; and Morrow, Lance (2003), Evil: An investigation, New York, Basic Books.

${ }^{4}$ An excellent discussion of the question of goodness can be found in the Introduction to Grant, Ruth W (ed) (2011), In Search of Goodness, Chicago, University of Chicago Press. Other discussions of human goodness can be found: Needleman, Jacob (2007), Why Can't We Be Good?, New York, Jeremy P Tarcher/Penguin Books; and Shermer, Michael (2004), The Science of Good and Evil: Why people cheat, gossip, care, share, and follow the golden rule, New York, Henry Holt. A major recent work arguing that humans have become more and more good as society has evolved is Pinker, Steven (2011), The Better Angels of Our Nature: Why violence has declined, New York, Viking. 
the actions of those who had saved lives as well as those who had saved elements of culture and gone out of their way to raise international awareness of what they had witnessed or experienced. There can be no greater act of righteousness than the saving of an innocent human life in danger, but what can we say about other acts of selfless courage that see people put themselves in danger to save the cultural, religious or other artefacts of another people's entire identity? They, too, have an important role to play in combating genocidal evil, given that genocide often seeks to destroy all traces of a group's existence. The issue was articulated in a short story by the Yiddish writer Chaim Grade, published in English in 1954:

Here in Paris there's an old lady, a Lithuanian. I know her well. Everybody knows that in the Vilna ghetto she saved the lives of Jews, and also hid books. The Germans sentenced her to death, but she was spared by a miracle. She's an old revolutionist, an atheist; that is to say, she doesn't believe in God.

Why do you think [she] saved the lives of Jews? [She] didn't try to make anyone an atheist; on the contrary, she hid our sacred books. [She] saved the lives of Jews not from pity alone, but for [her] own sake as well. [She] wanted to prove to [herself]...that the whole world does not consist only of criminals and those who are indifferent to the misfortunes of others. [She] wanted to save [her] own faith in human beings and the lives of Jews as well. 5

In this case, the old woman sought to reaffirm life in the face of the forces that would destroy life, of humanity in the face of those who would expunge it. The nature of the many acts in which people of good will can engage when seeking to

${ }^{5}$ Grade, Chaim (1954), 'My Quarrel with Hersh Rasseyner' in Howe, Irving and Greenberg, Eliezer (eds), A Treasury of Yiddish Stories, New York, Viking, 604. This short story was later the basis of a Canadian movie, The Quarrel (director Eli Cohen 1991). 
rescue humanity is immensely varied. But these acts serve to crack the edifice of terror, provide hope for others, and work for the defeat of those whose anti-human ideologies and goals threaten to return the world to a new Dark Age.

I have retrieved here but a few of these inspirational stories which might otherwise be lost and/or unrecognised. They are 'good' actions in the midst of the horror of genocide, and show what can be done in a positive and life-affirming sense, rather than through our continuing emphasis on the worst expressions of human behaviour as witnessed through the actions of the murderers. ${ }^{6}$

\section{Zoran Mandlbaum}

Zoran Mandlbaum is a former president of the Jewish community in the city of Mostar, the capital of Herzegovina. $\mathrm{He}$ is best remembered for having rescued innumerable Bosniaks during the Bosnian War of 1992-1995, earning the title of the 'Oskar Schindler of Bosnia'.7 Born on 9 September 1946, as a young Jewish boy growing up in post-Holocaust Yugoslavia he was all too aware of how the Nazis and their collaborators had murdered many members of his family, and was conscious of the need to take care of life in the face of atrocity.

When the war began, the Mostar Jewish community, first established in 1570, had a population of some 128 members. For one of the few occasions in the history of Western warfare, Jews were on this occasion not a target for any of the warring

${ }^{6}$ For the most part, these accounts are largely unknown to the general public, and have been drawn from Bartrop, Paul R (2012), A Biographical Encyclopedia of Contemporary Genocide: Portraits of evil and good, Santa Barbara CA, ABC-CLIO.

7 Schindler was a German industrialist who saved 1,100 Jews by employing them in his hardware factory, claiming that his products were essential to the Nazi war machine. 
parties, and the Jewish community was more or less ignored by the Serbs, Croats and Bosniaks. Faced with this unique circumstance, and mindful of the Holocaust experience that preceded him, Mandlbaum decided to achieve positive human out-comes rather than simply stand by.

At first he helped civilian Serbs leave Mostar for safer territory. He then began remarkable initiatives, using his position to serve as a go-between respected by all sides. This was especially valued by those being held as prisoners in notorious Croat-run concentration camps like Heliodrom and Dretelj, where conditions were harsh and inhumane, with severe overcrowding, inadequate medical and sanitary facilities, insufficient food and water, deficient ventilation, and in the summer, suffocating heat.

Mandlbaum tried to find ways to get letters, news and food to those imprisoned. At the same time, he was also active in trying to save lives and bring families together. Coming from a city whose various communities had been largely integrated, he helped reunite dozens of couples in mixed relationships within the wider community; secretly he took one or another of those separated in the divided city across the Neretva River and to their waiting partner.

His activities did not stop there. Recalling how Jews seeking to flee Nazi persecution were forced to have the letter ' $J$ ' stamped in their passports as a draconian discriminatory measure, Mandlbaum decided that this negative could be turned into a positive through the forging of false documents for Bosniaks. He arranged that their identity documents also bear the letter 'J' (in Croatian, Jevrejin or Jew), and thereby certify that the bearers were Jewish. With these new identities, people were able to procure official documents to enable them to leave the country (and in some cases, obtain release from the concentration camps). He issued more than 200 documents bearing a 'Jewish' identity, facilitating the holders to leave the war zone for Croatia or other countries. 
Soon after war came to Mostar, local Croatian forces gained control over most of the city. The Bosniak population west of the city centre were either expelled or sent to concentration camps. Those on the eastern side of the city were confined in a kind of ghetto, and lived through daily shelling and sniper fire. Cut off from the city and deprived of food supplies and medicine, the population soon found itself in crisis. Mandlbaum used his neutrality to bring in convoys of humanitarian aid. Managing to break through the military blockade, between 1993 and 1995 the Jewish community sent over 106,000 kilograms of food through to east Mostar, and thousands of letters from outside.

Unlike most residents of Mostar, Mandlbaum had the choice of whether or not to stay. He could have found safety elsewhere. Many Jewish families emigrated to Israel, or to Canada, Germany, Britain or Sweden. Closer to home, some moved to Croatia or Serbia. By the end of the war, it was estimated that only about 30 members of the Jewish community remained in Mostar. Mandlbaum could have stayed in the city to ensure the Jews were safe. But while doing this he remained in Mostar to help some of the innocent citizens who were in danger.

His efforts were not universally appreciated. During the war he faced a number of assassination attempts, was evicted from his apartment, and had his car blown up. When asked later why he put his own life at risk, he stated that as a Jew he called upon his religious heritage for inspiration at a time when he could otherwise easily have looked the other way. He was aware of the ruling in the Talmud that states: 'He who saves a life, saves a whole world' (Mishnah Sanhedrin 4:5; Babylonian Talmud Tractate Sanhedrin 37a), and that owing to the Jews' experience in World War II, Jews had a positive role to play in the future of Mostar. He was very conscious of his duty: in the fate of Mostar's Bosniaks, he recognised the historical fate of Jews everywhere. He wanted to show that people from different backgrounds, ethnicities and religions could live together. Zoran Mandlbaum continues to live in 
Mostar. His attitude today is the same as it was during the war: he did nothing special, only that which was right in the face of suffering.

\section{Sister Rachele Fassera, CMS}

Rachele Fassera is a Roman Catholic nun of the Comboni order, best known around the world for her efforts in rescuing almost all of the girls kidnapped from her school by members of the Lord's Resistance Army (LRA) in northern Uganda in October 1996. She was born in Pessina Cremonese, Italy, on 15 June 1946. At the age of 19 she gave up her job with an Italian electricity company to become a missionary. Joining the Comboni Sisters, she was posted to Uganda in 1982 where she taught biology and eventually became the deputy headmistress of St Mary's College for Girls, a residential boarding school in Aboke, northern Uganda.

Continuous war and massive killing of innocents was taking place in this region between the guerrilla army known as the Lord's Resistance Army (LRA), led by religious fanatic Joseph Kony, and the security forces of the Ugandan army. By 1986 the region had become completely devastated, with LRA slaughter and brutality, and the destruction of villages, homes, and schools the order of the day. The LRA made the kid-napping of children a priority: about 90 per cent of LRA soldiers were children under 16, and teenage girls were routinely forced to become sex slaves and 'wives' of the rebels.

At around 2:00 am on the night of 9-10 October 1996, some 200 armed members of the LRA broke into the dormitories of St Mary's College and abducted 139 girls aged between 13 and 16. They left at about 5:00 am, taking all the girls with them. After crisis discussions with other members of the faculty and the Mother Superior, Sr Alba, Sr Rachele and a young male teacher, John Bosco, decided to follow the rebels into the bush to rescue the girls. She took all the money she 
could find from the school office-enough to meet a ransom demand if there was one. The road was signposted with traces left by the rebels: food remains, discarded loot, and the like.

Eventually locating them later the same day, Sr Rachele immediately entered into negotiations with the commander, Mariano Ocaya. He was not interested in money, but offered instead to surrender some-though not all-of the girls. Making the offer that 109 of the girls could go, his trade-off was that 30 had to stay. Faced with this decision, Sr Rachele begged him for the lives of all the girls, offering her own in exchange for their freedom. He refused. If she did not accede to his demands, she was told, the LRA men would keep all 139. Thirty of the most attractive girls, already chosen by the rebels, would have to remain, and as an added trauma $\mathrm{Sr}$ Rachele herself would have to convey the news. After this, she was sent away with the 109 she had rescued, while the LRA and their captives slipped back into the bush.

Returning to Aboke, Sr Rachele immediately sought all possible means of freeing the girls, and appeals were made throughout the world to find ways of achieving their release. In a direct appeal to Pope John Paul II, she secured his support, and at his Sunday Mass on 20 October 1996 the Pope publicly called for the girls' freedom. This took the case to the international media, leading to other efforts to release the girls. Over the next several years, Sr Rachele met with United Nations Secretary-General Kofi Annan, United States First Lady Hillary Rodham Clinton, South African President Nelson Mandela, Libyan President Muammar al-Gaddafi, Sudanese President Omar al-Bashir, Zimbabwean President Robert Mugabe, presidents of a number of other African nations, members of the European Parliament, and many other diplomats. In short, the Aboke abductions and $\mathrm{Sr}$ Rachele's dramatic actions in pursuit of the LRA kidnappers drew what was up to that point unprecedented international attention to the insurgency in northern Uganda.

Waging her struggle for many years, Sr Rachele also 
sought every avenue to negotiate the release of other hostages as well as the Aboke girls, making contacts wherever possible with political, military, religious, and other organisations in the region. In June 1997, she met with LRA commanders in Juba, Sudan, who initially denied that they held the girls. After a standoff, the commanders admitted that they did have the girls, and offered to release them if the Ugandan military declared a ceasefire. The Ugandan government of President Yoweri Museveni rejected the proposal and stated that it was not responsible for anything that might happen to the girls. Constant political bickering of this sort undoubtedly set back their cause repeatedly throughout the early part of the 21st century.

Five of the 30 girls died in captivity, while over time all but two of those remaining eventually made their escape. On 14 March 2009, Catherine Ajok, the last of the abducted Aboke girls still held by the rebels, returned to Uganda with her 21month baby, who she said was fathered by Joseph Kony.

The story of Sr Rachele Fassera's action is an outstanding example of how to live by the courage of one's convictions, even at personal risk, and then to seek a peaceful solution through negotiation and dialogue. Her efforts helped bring world attention to the LRA's practice of abducting children, and even forced the Museveni government to start direct negotiations with Sudan in an effort to obtain the Aboke girls' release. ${ }^{8}$

8 See also De Temmerman, Els (1995), Aboke Girls: Children abducted in Northern Uganda, Kampala, Fountain. With regard to the Lord's Resistance Army, a useful starting place is Eichstaedt, Peter (2009), First Kill Your Family: Child soldiers of Uganda and the Lord's Resistance Army, Chicago, Lawrence Hill Books. 


\section{Jakob Finci}

Jakob Finci, a native of Sarajevo, is a leading member of the Bosnian Jewish community. During the Bosnian War of 19921995, as president of La Benevolencija, Bosnia's Jewish cultural, educational and humanitarian society, he provided medical and relief supplies and arranged for the evacuation to safety of over 3,000 people of all backgrounds.

Originating from a family that arrived in Sarajevo in the mid-16th century after the Jews' expulsion from Spain, Finci was born on 1 October 1943, soon after his parents had been liberated from an Italian internment camp. He graduated in law from the University of Sarajevo in 1966, and became an expert in international trade law. With war looming, in 1991 he set to work to bring goodness to his city. He was among a number of those again supporting the establishment of $\mathrm{La}$ Benevolencija, a Jewish cultural, educational and humanitarian society first established as far back as January 1892 for the purpose of fostering Jewish culture and tradition, rescuing Bosnian Jewish history, assisting with educational activities, and providing humanitarian assistance and health care to those in need. ${ }^{9}$

As vice-president in 1991, and then president from 1993, Finci directed an organisation that became the only local body delivering humanitarian relief on a non-sectarian basis. With the conflict spreading from Slovenia to Croatia during 1991, La Benevolencija managed to get medicine through the front lines to a small group of elderly Jews trapped in besieged Dubrovnik. In Sarajevo, Finci and his colleagues stockpiled medicines and foodstuffs sufficient to get through the winter. When the first shots were fired in the Bosnian War in April

${ }_{9}$ The website for the reconstituted La Benevolencija, outlining its many contemporary activities as well as its international connections, is: http://www.benevolencija.eu.org 
1992, the organisation immediately planned and carried out the first evacuation of children and the elderly. $\mathrm{La}$ Benevolencija also opened a soup kitchen, serving 300 hot meals a day, seven days a week, for anyone who arrived.

The commitment shown by Finci, Ivica Ceresnjes, the thenpresident of the Jewish community of Bosnia-Herzegovina, and countless volunteers, saw remarkable humanitarian work undertaken during the siege of Sarajevo. In the first two years of the siege, La Benevolencija opened three pharmacies and dispensed 1.6 million prescriptions; opened the city's only clinic, where multi-ethnic staff tended 25,000 patients; gave away 380 tonnes of food; served 110,000 hot meals in the soup kitchen; started a postal service that handled 100,000 letters; set up a two-way radio connection with the outside world; looked after refugees from elsewhere in Bosnia; and started a thriving Sunday school for 50 children, only 20 of whom were Jewish.

On account of La Benevolencija's Jewish identity, the organisation found itself in a unique position of neutrality. Finci sought, and received, clearances from all warring parties that eventually enabled nearly 3,000 people, in 11 mixed rescue convoys of Muslim, Croat and Serb families, to flee the country. Somehow, the organisation managed to obtain permission from the Bosnian government for people to leave, negotiated safe passage from the Serbs, and arranged their entry to Croatia. Finci also arranged for 'new' Jews to leavepeople who arrived at La Benevolencija headquarters stating that they had suddenly discovered a long-lost Jewish connection in their family. Among his many activities, Finci smuggled people out on false documents, even arranging for one elderly Muslim couple to use his own late parents' identities (and papers) as a way to clear Serb roadblocks.

Arranging for food convoys was not easy. Finci and his colleagues had to negotiate with all sides, and clear a path through up to 38 different checkpoints between Sarajevo and 
the ingress port of Split, Croatia. Finci would himself accompany La Benevolencija's two trucks to Split each month to get the much-needed supplies, and soldiers on all sides respected the efforts of the Jewish welfare body.

In 1995, Finci became the first elected president of the Jewish community of Bosnia-Herzegovina. By war's end, he had become one of Bosnia's most respected public figures. The esteem in which he was held saw him as one of the founders, in 1997, of a new Interreligious Council of Bosnia and Herzegovina (IRC), which worked towards reconciliation between the three ethnic groups, seeking to achieve peace and co-existence through the building of tolerance and a civil society. In February 2000, he was also elected chairman to a national committee charged with setting up a truth and reconciliation commission.

In an ironic twist, in 2008 Finci - though ineligible to run for parliament or the presidency owing to the terms of the Dayton Peace Agreement which only allows Serbs, Croats and Bosniaks to run for public office-was appointed to represent his country when he became the ambassador of Bosnia and Herzegovina to Switzerland.

\section{Mbaye Diagne}

Mbaye Diagne was a Senegalese army officer who worked as a United Nations Military Observer (MILOB) in Rwanda before and during the 1994 genocide. One of nine children, he studied at the University of Dakar before joining the Senegalese army. In 1993 he was assigned to the United Nations Assistance Mission for Rwanda (UNAMIR) covering the implementation of the Arusha peace settlement. He was stationed at the Hôtel des Mille Collines, one of Kigali's luxury hotels and the scene of a major sustained rescue of Tutsi throughout the genocide. ${ }^{10}$

10 This was the location of the efforts by the hotel manager, Paul 
Within hours of the start of the genocide on 6 April 1994, Diagne decided that his orders not to intervene were unacceptable. The morning after the assassination of President Juvénal Habyarimana, the next in line of succession, the moderate Hutu Prime Minister he Uwilingiyimana, was herself assassinated, with her husband, by Presidential Guards. Learning of Uwilingiyimana's murder, Diagne decided to investigate by going to the scene of the crime. There he found the Prime Minister's five children hiding in the adjoining housing compound of the United Nations Development Program. After a fruitless wait for UN evacuation trucks, he put the children into his own vehicle, hid them with blankets, and returned them to the relative safety of the Mille Collines. He then faced the problem of finding a way to evacuate them, undetected, to the airport, crossing the various checkpoints established by the Interahamwe militias, and once there, to obtain a passage for them out of the country. He achieved this and the children were removed safely on a Canadian transport that took them to Nairobi in Kenya.

It was a reckless and risky move, but would be only the first of many occasions on which the young officer would ignore the standing orders from UN headquarters to remain neutral. As a MILOB, his job was to try to find ways to prevent conflict and report on what he had seen; it was essentially a liaison and investigation role in which he was under orders not to get involved in any way. That was not what Diagne did. In the weeks following the start of the

Rusesabagina, to save the lives of over 1,200 people during the genocide. His means of doing so have since attracted considerable critical attention. See Rusesabagina, Paul (2006), An Ordinary Man: An autobiography, New York, Viking. The movie version of Rusesabagina's experience, Hotel Rwanda (director Terry George, 2004) predated by two years the appearance of his autobiography. 
genocide, he worked hard to save the lives of hundreds of Rwandans, charming his way past the militias, smiling, joking, sharing cigarettes with the murderers, and over and over again talking his way through the roadblocks. His solo rescue missions, nearly always at great peril to himself, attained legendary status among the UN forces in Kigali.

Diagne's strength lay in his ability to persuade others of his friendliness and comradeship. His disposition helped him gain the confidence of families, groups, and leaders to all parties in the conflict. On occasion he would have to pass through up to 23 Interahamwe checkpoints to get to the people he was trying to save. The Interahamwe, who, depending on the time of day, could be drunk or drugged, had to be convinced on each occasion that he was not harbouring Tutsi. Diagne would find Tutsi who were hiding, drive them back through the same checkpoints, and then relocate them-often in the Amahoro Stadium, from where he would then ferry them to some other place of refuge. He was forced to undertake countless missions, as he could only carry three to four (sometimes, five, though this was extremely hazardous) at a time. Once, he spent an entire day operating in precisely this fashion after he came across a group of 25 Tutsi hiding in a house in Nyamirambo, Kigali. On each occasion he bluffed his way through roadblocks. He relied on his extensive contacts among the Hutu military and militias, his ability to defuse tense situations owing to a sharp sense of humour, and, from time to time, bribery in the form of cigarettes or money. His dynamism saw him seemingly everywhere at once.

It certainly helped that in his position as a MILOB he had access to most of the city and was known widely by all sides of the conflict. But in engaging in his acts of selflessness, he was repeatedly forced to flout his standing operational orders. UNAMIR's commander, General Roméo Dallaire, was aware of what Diagne was doing, but neither stopped him nor reprimanded him. While everyone in the UN establishment seemed to know of Diagne's actions, some believed that 
Dallaire would not discipline him because it was a role Dallaire himself would have preferred to be doing. ${ }^{11}$

On 31 May 1994, Diagne was driving alone back to UN headquarters in Kigali with a message for Dallaire from the Chief of Staff of the Rwandan Armed Forces, Augustin Bizimungu. At this time the rebel Rwandan Patriotic Front (RPF) was closing in on Kigali, and engaging in fierce fighting with the Rwandan army. A random mortar shell, fired by the RPF towards a Hutu extremist checkpoint, landed behind his jeep. Shrapnel entered the rear window and hit Diagne in the back of the head, killing him instantly.

Mbaye Diagne was universally recognised as a real-life hero of the Rwandan genocide. On learning of his death, UNAMIR Force Headquarters held a minute of silence in his honour, and a small parade took place at Kigali airport on 1 June. A devout Muslim, he was buried in Senegal with full military honours. Later, his wife and two small children accepted, on his behalf, the UMURINZI Campaign against Genocide Medal awarded by Rwanda. ${ }^{12}$

\section{Vedran Smailović}

Vedran Smailović, known throughout the world as 'The Cellist of Sarajevo', was an inspirational musician whose playing of Tomaso Albinoni's Adagio in G Minor during a crucial time in the Bosnian War brought home to the West the horror of the siege of Sarajevo in a particularly poignant

${ }^{11}$ Dallaire's views on Mbaye Diagne can be found in Dallaire, Romeo and Beardsley, Brent (2003), Shake Hands with the Devil: The failure of humanity in Rwanda, Toronto, Random House Canada, 400.

12 Extensive interviews with people who knew Diagne in Rwanda have been reproduced in the on-line resources accompanying the Frontline documentary Ghosts of Rwanda (director Greg Barker, 2004) http://www.pbs.org/wgbh/pages/frontline/shows/ghosts 
manner. Born in Sarajevo on 11 November 1956, he came from a family of musicians. As an adult, the highly talented Smailović became well known for his playing with the Sarajevo String Quartet. He also played with the Sarajevo Opera, the Sarajevo Philharmonic Orchestra, the Symphony Orchestra RTV Sarajevo, and with the National Theatre of Sarajevo.

After the outbreak of war in April 1992, Smailović was confident that the city's unity and pluralistic values would prevail over the destruction that was taking place in other parts of Yugoslavia, and that it would be impossible to destroy such strong communal harmony. This ideal kept him buoyant during the siege, and enabled him to tolerate the cold, the food, power and water shortages, and the constant mortar bombings and sniper fire from the Bosnian Serbs in the hills surrounding the city.

On 27 May 1992 this attitude changed. A long queue waited patiently on Vaso Miskin Street for bread, in front of one of the last functioning bakeries in the city, and at approximately 10:00 am a mortar shell hit the line, killing 22 people and wounding 160 more. Others died in subsequent days. Enraged by what had happened and feeling powerless, Smailović decided he would at least try to raise the world's consciousness. He would protest the senseless killing, in a very public way, through his music. For the next 22 days, in honour of each of those killed in the bombing, Smailović gave a performance of Albinoni's Adagio - in ruined homes, in the open, in the smouldering remains of the National Library. His approach was simple. Dressed in formal attire as he was when playing for the Sarajevo Symphony, he would seat himself on a battered camp stool to play his music. Sometimes the sounds of war would drown him out, but he continued playing.

His heroic antiwar statement drew world attention, though in the constant retelling of the story of 'The Cellist of Sarajevo' some of the detail was lost. (For example, word was 
conveyed that Smailović would always play at 4:00 pm, in the same place as where the mortar hit-notwithstanding that the attack took place at 10:00 am, or that Smailović varied his location so as not to get shot by sniper fire.) His protest didn't end after 22 days; indeed, he had been playing since the siege began until he left Sarajevo in December 1993, often playing for free at funerals, in graveyards and bombsites.

As his story began to circulate, Smailović became a symbol for peace in Bosnia. An English composer, David Wilde, was so moved by Smailović's defiant act that he wrote a composition for unaccompanied cello, simply called 'The Cellist of Sarajevo'. One of the world's most accomplished cellists, Yo-Yo Ma, then played this piece at the International Cello Festival in Manchester in 1994 with Smailović present. Several other creative artists, from rock bands to folk singers, have also paid tribute to Smailović. ${ }^{13}$

Vedran Smailović managed to leave Sarajevo in December 1993, relocating to Northern Ireland. Celebrated as a musician who defied the city's snipers, Smailović showed that the human spirit can resist as powerfully as the physical kind. He would not succumb to terror, making a statement that the forces that would destroy his city could not destroy the spirit of the people.

${ }^{13}$ A controversy arose in 2008 after use was made of a character based on Smailović in a novel by Canadian author Steven Galloway (2008), The Cellist of Sarajevo, Toronto, Vintage Canada. Upon learning of the novel's existence, Smailović publicly expressed his outrage over the appearance of a book that used his persona without authority, and with no possibility of financial compensation. He was incensed by the novel, which he saw as capitalising on his act. Galloway has repeatedly denied this; rather, he has asserted, he was paying tribute to Smailović through literature. 


\section{Father Vjekoslav Ćurić}

Vjekoslav 'Vjeko' Ćurić was a Bosnian Croat Franciscan priest and humanitarian, best known for his role in helping to save Rwandan Tutsi threatened with annihilation during the genocide of 1994. Born in Lupoglava, Bosnia-Herzegovina on 26 April 1957, he studied in Visoko, central Bosnia, and in Sarajevo. He entered the Franciscan order, and was ordained on 21 June 1982. On 18 August 1983 he began his missionary work in Rwanda, one of the first volunteers of the Franciscan Africa Project.

It was in Rwanda, during and after the genocide of 1994, that Curić's service was at its most intense. Reportedly one of only two non-African Catholic priests to remain in the country throughout the genocide, his actions saved hundreds of lives. He revealed later that he had sheltered many Tutsi from the Interahamwe and Impuzamugambi militias, having secretly ferried them out of the country in the bottom of his truck. At the beginning of the genocide, he similarly saved the lives of a number of white clergy-many of them Belgian priests, monks and nuns - who were in danger. He allegedly received an order direct from the Vatican to leave the country, but refused to do so, claiming that while his flock was in danger he could not abandon them.

By 1994, Ćurić was a long-term resident of Gitarama, working to help develop his parish of Kivumu. He was wellknown and liked, and when the killing got under way in April and May the local people looked to him for rescue. Curić remained in the country at a time when almost all expatriates were leaving. True to his ideals, he made a stand with the people of Kivumu. He threw himself into the work of providing assistance to all who could reach him, as well as helping others to escape. He continued preaching the Gospel, condemning the violence and calling for peace.

After the genocide, Curić continued his work in Kivumu. He helped resettle widows and re-establish their shattered 
lives, and set up educational projects for children. He remained impartial throughout, helping both Hutu and Tutsi rebuild their shared community, blind to the differences that had so divided them just weeks earlier. For this, he was viewed by many Hutu as a Tutsi collaborator. In 1996, he escaped an attempt on his life but still refused to leave, against the advice of many. His attitude was that he had stayed during the genocide and would not abandon his congregation now that peace had come.

On 31 January 1998, he was shot in his car, murdered in the heart of downtown Kigali. The perpetrators are not known. The Catholic Church immediately declared that he had gone to a martyr's death after devoting himself to the rescue of others for the glory of God and love of his neighbours. He was buried in Kivumu, the community he had served without interruption for 15 years, in a church which he and his congregation had built. His funeral was attended by Rwandan Prime Minister Pierre-Célestin Rwigema and other members of the government, along with a vast number of Catholic and other Christians, as well as representatives from the Jewish and Islamic communities.

Some in Rwanda refer to Ćurić as Africa's 'Oskar Schindler'. In 2005, Ćurić's story formed the backdrop of a movie about Rwanda, Shooting Dogs (directed by Michael Caton-Jones), released in the United States as Beyond the Gates. The writer of the original story, David Belton, was also the movie's producer; both he and the screenwriter, David Wolsencroft, knew Curić in Rwanda in 1994, as he had saved them from the militias on a number of occasions. They employed their memories of Ćurić as the inspiration for one of the film's leading characters, Father Christopher, played by the British actor John Hurt.

\section{Inela Nogić}

Inela Nogić is a Bosniak woman who achieved worldwide 
fame at 17 when, during the siege of Sarajevo, she won the 1993 Miss Sarajevo beauty pageant, held in a basement to avoid sniper attacks from Bosnian Serb militias. Born into a strict Muslim family in 1976, she was a good student at school. With the outbreak of war in Bosnia in 1992 her neighbourhood became known colloquially as 'Little Hiroshima' because of the destruction that soon ravaged it, but Nogić and her friends decided to make the best of the situation by not succumbing. An attractive young woman in a city renowned for what some have termed 'Sarajevo style' - a combination of French chic and Italian flair-the pretty blonde commented to reporters during the siege that maintaining a good appearance through attention to hair and make-up was a way for young women to show those bent on their murder that youth, beauty and life could win out over the forces that would destroy them.

In 1993, Inela Nogić became the symbol of that attitude for all young Bosniak women. As the siege continued, the idea of organising a beauty pageant, 'Miss Sarajevo 1993', came from a group of young Sarajevans committed to maintaining the life of the city and showing the world that the conditions under which they were living were intolerable even though their spirit would not be broken. Inela Nogić was encouraged to enter by her mother. European aid agencies and NATO administrators, taken with the idea of a beauty pageant right under the noses of those seeking the destruction of the city, ensured that the contest, which took place on 29 May 1993, would be transmitted across the world. While inspiring, it was also sad to watch. Many of the young women participating, clearly affected by the siege and the war, appeared undernourished and sickly. At the end of the pageant, in an especially poignant moment, Nogić and the other contestants held up a banner that read 'DON'T LET THEM KILL US!'

An American journalist and film director, Bill Carter, had arrived in Sarajevo in the winter of 1993 to work with the Serious Road Trip, an aid organisation founded in London in 
1991 for delivering food to orphans affected by war. In Sarajevo he shot hundreds of hours of video, including coverage of the Miss Sarajevo pageant. In later discussions in Italy with Bono, the lead singer of the rock band U2, Carter suggested a documentary based on Sarajevo's underground resistance movement. Bono reputedly jumped at the idea; not only to produce the film, but also to provide the necessary funds. The result was Miss Sarajevo. Subsequently broadcast across the globe, it provoked a viewer response calling for an end to the siege and the bloodshed. Later, Bono and U2, together with Brian Eno, and featuring a cameo solo by Luciano Pavarotti, used footage from the movie to create a film clip for a single of the same name. Inela Nogić was featured on the cover. ${ }^{14}$

Popular imagination soon created the urban legend that the winner of the Miss Sarajevo pageant had been killed by sniper fire, but it is possible to speculate that the pageant may have potentially saved Inela Nogićs life. As a result of the publicity, she met a Dutch journalist, and a year later the couple moved to the Netherlands, where they settled down and had two children. She then studied graphic design, and took up residence in Amsterdam.

In 1997, U2 was scheduled to perform in Sarajevo, the first rock band able to host a concert in the city since the end of the war. Bono contacted Nogić, then doing modelling work in France. He organised for his private plane to take her from Nice to Sarajevo where she was met by NATO military authorities. They escorted her to the concert at the Koševo Stadium along with the band members, and Bono sang Miss Sarajevo in her presence as U2's special guest.

14 On his quest to bring news and awareness of the plight of Sarajevo to the world, see Carter, Bill (2005), Fools Rush In: A true story of love, war, and redemption, 2nd edition, Tuscon AZ, Schaffer Press. 
Nogić was to say later that the objective of the pageant was to show that the war was about more than just men and guns, but that women had a part to play in defying the aims of the killers. In Balkan tradition-whether it is Serb, Bosniak or Croatian - the noun 'inat' translates roughly into a notion of actions taken 'in spite of the consequences'. It embodies a spirit of defiance regardless of what might come next. Nogić's inat was thus symbolic of a wider defiance relating to Sarajevo's struggle to retain its humanity.

\section{Conclusion}

What can we learn from these brief descriptions? Are these men and women representative of how all 'good' people behave during genocide? To recall my student's question about a hierarchy of righteousness, is there not a significant difference between people who work to save lives - a beauty queen and a musician-regardless of the same environment of horror in which their actions were played out?

Many scholars have attempted to answer the question of why people engage in altruistic acts. The literature is now substantial, with much of it concluding that, at base, people are really decent, and that outbreaks of radical evil occur only under the most extreme conditions. More often than not, such literature fits into a self-help model designed to reinforce the 'you can do it' approach of that large and growing genre. (Few, on the other hand, have taken the other approach and tried to consider why people do not help. In 1970 two psychologists, Bibb Latané and John M Darley, wrote The Unresponsive Bystander: Why doesn't he help?, based on a series of human laboratory experiments they had undertaken earlier. ${ }^{15}$ ) Resistance to genocidal evil takes place for many reasons, some of which have been sketched in this essay. Why do people put themselves on the line to save others - or, in

${ }^{15}$ Latané, Bibb and Darley, John M (1970), The Unresponsive

Bystander: Why doesn't he help?, Englewood Cliffs NJ, Prentice-Hall. 
lieu of that, the culture of others? The question is as broad as it is difficult to answer. Some reasons will include religious and ethical beliefs; resistance against those occupying their country or perpetrating war crimes, crimes against humanity, and other massive human rights violations against fellow citizens; simple, human anger at the atrocities they were witnessing; and a sense of compassion for those in a worse position than themselves, regardless of ethnic, racial, religious, political, social or national circumstances. ${ }^{16}$

The accounts highlighted here-each different from the other, in many ways - point to one unifying fact: that people can make a difference, even amid dire of situations. 'Goodness' is very much a notion dependent on the opinion of the beholder, making it often impossible to define it in a universally acceptable manner. As applied to genocide, perhaps we can rest with the view of United States Supreme Court Justice Potter Stewart to describe his threshold test for pornography in Jacobellis vs Ohio (378 US 184, 1964): 'I know it when I see it.' Hardly scientific, it is nonetheless a starting point for further discussions relating to the positive behaviour that illuminates, however faintly, the awful darkness of genocide. Indeed, it is that very light that ensures that the act of saving humans can also be one that saves humanity-a necessary act of grace for us all, lest the world despair at its own impotence in the face of the destructive side of the inclination of mankind to perform acts of unalloyed evil.

${ }^{16}$ A recent work has appeared suggesting that others are also beginning to see a need to examine this issue of why. See Press, Eyal (2012), Beautiful Souls: Saying no, breaking ranks, and heeding the voice of conscience in dark times, New York: Farrar, Straus and Giroux, 2012. 